\title{
Effect of Macroeconomic Variables on Financial Performance of Healthcare Manufacturing Firms in Nigeria
}

\author{
Dr. Ifeyinwa Elizabeth NNAJIEZE (Correspondence author) \\ Enugu State University of Science and Technology, Enugu, Nigeria \\ E-mail: judethadeusoshim@gmail.com \\ Anthony Okorie Nwabuisi \\ Enugu State University of Science and Technology, Enugu, Nigeria
}

\author{
Alex Onyeji Igwe \\ Department of Accountancy, Faculty of Management Sciences \\ Enugu State University of Science and Technology, Enugu, Nigeria \\ E-mail: dennisifeyinwa@gmail.com
}

Received: July 5, $2021 \quad$ Accepted: Nov. 17, $2021 \quad$ Published: December 28, 2021

doi:10.5296/ajfa.v13i2.18929 URL: https://doi.org/10.5296/ajfa.v13i2.18929

\begin{abstract}
This study empirically investigated the effect of macroeconomic variables on financial performance in Nigeria healthcare sector. It spanned from 2008 to 2018 and utilized annual time series secondary data extracted from annual reports and financiall statements of the selected firms. The ex-post facto research design was adopted while analytical techniques employed were descriptive statistics, fully modified ordinary least squares panel regression and Pearson correlation analysis. Findings revealed that changes in macroeconomic indices play significant roles in the financial position of Healthcare manufacturing firms in Nigeria. Particularly, the result showed that exchange rate, interest rate, extermal debt and trade openness have a negative effect while inflation rate exerts a positive influence on the financial position of Healthcare manufacturing firms in Nigeria. Among the selected macroeconomic variables, the effects of exchange rate and inflation rate were significant. The
\end{abstract}


result implies that an unstable macroeconomy is harmful to the healthy growth of Healthcare manufacturing firms in Nigeria. The study, therefore, recommended among other things that the exchange rate should be monitored while economic policy measures aimed at controlling the exchange rate in Nigeria should be established. A high rate of interest should also be regulated and set to a rate favourable to the growth of Healthcare manufacturing companies in Nigeria. The federal government of Nigeria should work towards reducing their level of borrowing from foreign countries and as well reduce the volume of trade openness for the overall performance of the manufacturing sector in Nigeria.

Keywords: Exchange Rate, Interest Rate, External Debt, Trade Openness, Inflation Rate, Financial Position 


\section{Introduction}

\subsection{Background to the Study}

The association between macroeconomic factors and organizational performance has piqued the interest of researchers studying this phenomenon. Key macroeconomiic variables such as the currency rate, interest rate, inflation, and gross domestic product are usually assumed to have an impact on an organization's performance. These are external factors that influence how things work on a daily basis.

The efficacy of financial institutions is influenced by a number of variables, including economic variables and institution-specific factors. Social, environmental, and political events, as well as suppliers, competitors, and government rules and policies, are all macroeconomic factors outside of the firm. According to Otambo (2016), macro-economic variables are factors that have a broad impact on a country's economic situation on a regional or national scale. Economic variables are used to evaluate the performance of a country's economy. Important economic factors include the Consumer Price Index (CPI), Gross Domestic Product (GDP), unemployment, stock market index, corporate tax rate, and interest rates (World Bank Group, 2015; Broadstock, Shu and Xu, 2011).

Waiyaki (2017) defines performance as a constant process of improving individual performance by aligning actual performance with the desired organizational goal. In general, one of the most essential factors of an organization's success or failure is its performance. The financial performance of a company is a quantitative term that measures how efficiently it assesses its resources to generate profit (Omollo, Muturi and Wanjare, 2018). As a result, financial performance can be described as how well a company's financial goals are being met or have been met. It assesses a company's long-term financial viability. Because it is so important to shareholders (in the form of returns on their investment), managers (in the form of compensation), creditors (firms' ability to repay), and the government, a firm's financial performance has a significant impact not only on its sources of financing, growth, and survival, but also on the larger economy (tax purposes). The capacity of a company's financial performance to get both internal and external financing, as well as its ability to develop and survive, can have a substantial impact on its survival.

Financing, investment, and operational decisions are just a few examples of operational and strategic decisions that are regularly influenced by the macroeconomic environment (Owolabi, 2017). As a result, macroeconomic indicators including the Consumer Price Index (CPI), exchange rate and inflation rate fluctuations, government spending, and interest rates are widely used to evaluate performance. Macroeconomic factors have an impact on a firm's performance (Egbunike and Okerekeoti, 2018; Issah and Antwi, 2017).

The economic performance of an economy is measured by the stability of macroeconomic variables such as the exchange rate, inflation rate, consumer price index, Gross Domestic Product, stock market index, and interest rates. At both the macro and micro levels of an economy, policymakers expect that these variables will remain stable and favorable in order for the economy to continue to grow. Furthermore, new and existing investors hope that these 
macroeconomic factors remain favorable so that the value of their investments does not suffer. When the economy is performing well, most investors and shareholders expect businesses to do well as well, resulting in an increase in total wealth.

Financing, investment, and operational decisions are just a few examples of operational and strategic decisions that are regularly influenced by the macroeconomic environment. Owolabi (2017). Internal and external factors impact a company's profitability; the internal aspect focuses on the company's ability to increase productivity and reduce expenses, whilst external factors include the exchange rate, GDP, the status of the economy, unemployment rate, government regulation, and so on. However, macroeconomic indices such as the interest rate, gross domestic product, inflation rate, regulatory policies, and the like have a substantial impact on firm financial performance, which is comprehensible.) As a result, the purpose of this study is to provide macroeconomic variables that impact profit or performance to manufacturing healthcare enterprises, thereby alleviating the problem of operational losses caused by macroeconomic variable instability.

\section{Literature Review}

\subsection{Conceptual Review}

The exchange rate is the value of one country's currency in terms of another country's currency. It's one of the macroeconomic factors influencing Nigerian companies' financial performance. Over time, Nigeria's exchange rate has evolved from a regulated to a deregulated system. According to Osundina, Osundina, Jayeoba, and Olayinka (2016), the exchange rate is completely determined by market forces, as opposed to the current system, in which monetary authorities intervene in the foreign exchange market only when strategic goals are met.

Borrowers' rental payments for using credit are interest rates, while lenders' return for parting with liquidity is interest rates (Gikonbo and Mbugua, 2018). For the borrower, interest is a cost, but for the lender, it is a source of money. Interest rates are usually charged monthly or annually (per annum), and they are determined by and directly tied to the risk levels of the borrower.

According to Oleka (2006), inflation is the creation of money that raises the price of goods while diminishing the naira's purchasing power. It is the steady acceleration of the rate of price increase over time. Inflation is defined as a pervasive and persistent rise in the aggregate level of prices measured by an index of the cost of various goods and services. War, religious turmoil, political instability, poor harvests, environmental upheavals, abduction, and other societal maladies all contribute to inflation.

Chen (2018) defines debt as money borrowed from one party by another. The share of a country's debt owed to foreign lenders such as commercial banks, governments, and international financial institutions is referred to as external debt. According to Ijirshar, Joseph, and Gadoo (2016), external debt is a financial commitment that links one party (the debtor country) to another (the creditor country) (lender country) 
Trade openness refers to a country's economy's outward or inward direction. Economic policies that restrict or encourage cross-border trade are measured by trade openness. Some of the trade policy considerations that countries make to facilitate outward or inward orientation include trade obstacles, import-export, infrastructure, technology, scale economies, and market competitiveness. Trade openness encourages effective resource allocation, accumulation of factors, technological diffusion, and knowledge spilloversi (Wang, 2016).

Return on assets (ROA) is a measure of a company's profitability in relation to its total assets, according to Onyekwelu, Nnadi, and Iyidiobi (2018). ROA is calculated as a percentage by dividing a company's annual income by its total assets.

The return on assets (ROA) measures how well a company's assets are used to generate profits.

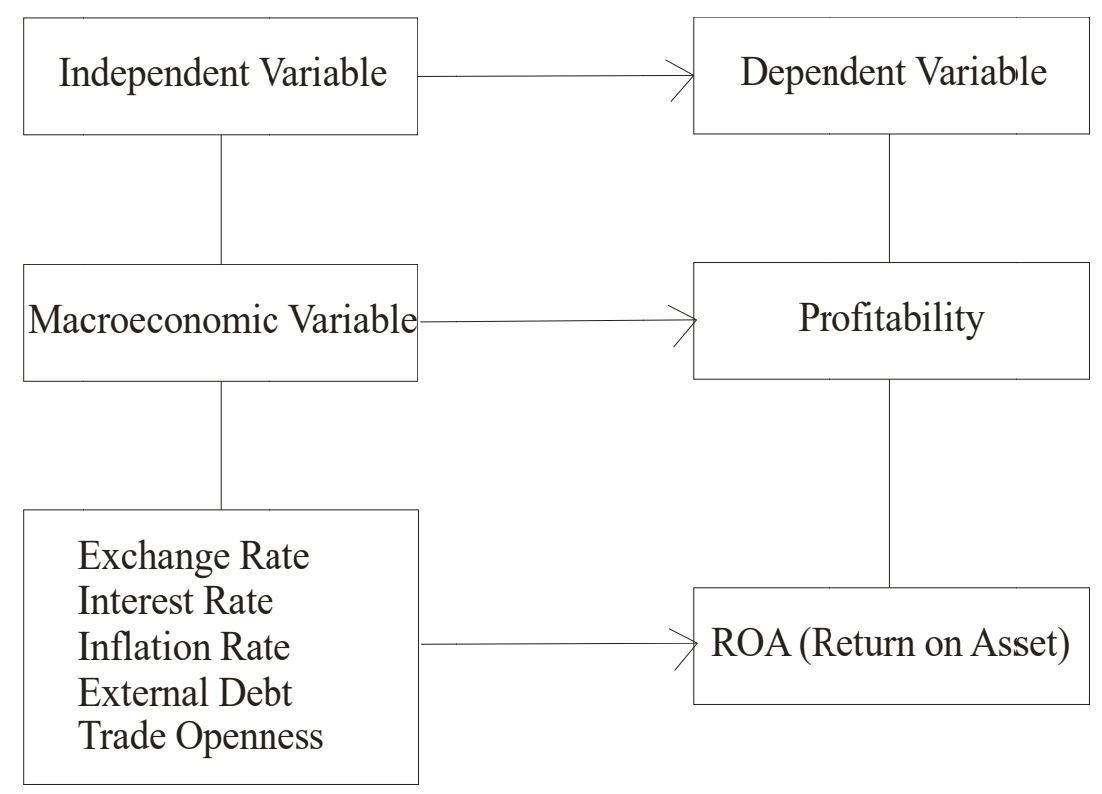

Fig. 1. Conceptual Framework of the relationship between Macroeconomic variables and Profitability

Source: Author's conceptualization

\subsection{Theoretical Framework}

\subsubsection{The Keynesian theory of interest rate}

In 1936, John Maynard Keynes' "General Theory of Employment, Interest, and Money" was published, kicking off the Keynesian revolution. According to the Keynesians' model, interest rates fall as the money supply expands, ceteris paribus, resulting in a negatively sloppy demand curve. The model assumes a constant money supply, hence the interest rate is mostly driven by money demand. According to Keynes, the supply and demand for money are the primary determinants of interest rates (Osadume, 2018). According to Keynes' analysis, there are three motives for holding money: transaction, precautionary, and speculative motives. 


\subsubsection{Purchasing Power Parity Theory}

The Purchasing Power Parity (PPP) theory is a method for determining, exchange rates. It asserts that the change in relative price levels of two currencies over time influences the change in their exchange rate. The inflationary theory of exchange rate movements gets its name from the theory that it focuses on price level change as the key driver of exchange rate fluctuations. According to Coakley, Flood, Fuertes, and Taylor (2005), when a home country's currency is converted to foreign currency in absolute terms, it will have similar purchasing power. According to Coakley, Flood, Fuertes, and Taylor, home currency should always buy a similar basket of goods in a foreign country. Changes in nominal price levels between countries are represented by variations in national prices based on relative PPP. The theory applies in this study because the chosen Healthcare manufacturing company does both local and international business, necessitating the use of both local and foreign currency, which has an impact on the company's financial performance.

\subsubsection{The Pecking Order Theory}

Two works that contributed to pecking order theory are Myers (1984) and Myers and Majluf (1984). (1984). Its belief was based on Donaldson's (1960) argument that financing practices imply expectations, and that managers would make financial decisions in order to eliminate inefficiencies in the company due to information asymmetry. Businesses, according to the theory, have financial optimization concerns. As a result, a company will prefer internal financing to external financing, and debt financing over stock financing will be favoured. The theory stated that in less developed countries with less developed financial systems, finance sources are opaque, forcing them to rely on internally generated funds as well as borrowing from banking institutions for external funding needs, thereby contributing to the country's economic situation.

\subsubsection{Fisher's effect theory of Inflation}

The Fisher effect theory of inflation, introduced by Pandey (2009), looks at the effects of inflation from two perspectives: aggregate demand and cost of production. During periods of high inflation, consumers with fixed incomes have less purchasing power because the value of money has declined, resulting in fewer demand for goods. Inflation alsio raises production costs, reducing profit margins. Pandey went on to explain that if capital markets were perfect, equal-risk investments in various countries should yield equal returns. This is due to the arbitrage process, which entails a continuous transfer of funds from one country to another until a state of equilibrium is achieved. The nominal interest rates will adjust perfectly to the change in inflation rates due to the fisher effect if the real rates of return in two countries are the same.

\subsubsection{Comparative Advantage Trade Theory}

This theory was first proposed by Ricardo in 1958. Openness at the country level, according to the theory, leads to growth gains through specialization, innovation investment, productivity increase, or improved resource allocation. According to the theory, allowing a country to open up to the outside world helps it to reallocate scarce resources to more 
productive sectors, resulting in increased total productivity. Furthermore, according to the theory, higher factor productivity leads to longer growth gains, but the intermediate impact is likely to be negative, implying a $\mathrm{J}$ curve reaction.

As a result, the Pecking Order theory, which emphasizes financial optimization in an organization, is used in this study.

\subsection{Empirical Reviews}

Ubesie (2016) looked at the effect of foreign exchange fluctuations on the Nigerian economy's financial depth. From 1985 through 2015, the study used secondary time series data. The data was examined using the multiple regression analytical approach of Ordinary Least Squares (OLS), which included the unit root test of time series data stationarity. According to OLS regression studies, fluctuations in foreign exchange in Nigeria have not had the expected beneficial effect on the depth of the Nigerian financial industry. This means that Nigeria's economy has a lengthy history of failing to achieve a stable exchange rate that attracts foreign investment.

Using multiple linear regression, Egbunike and Okerekeoti (2018) explored the relationship between macroeconomic conditions, corporate characteristics, and financial performance of listed manufacturing enterprises in Nigeria. The findings revealed that while interest rates and exchange rates had no effect on ROA, inflation and GDP growth rates did. Furthermore, firm size, leverage, and liquidity were also important factors.

Odior (2013) looked into the impact of Nigerian industrial production on macroeconomic conditions. For 37 years, the data was examined using ordinary least squares regression models (OLS). The research revealed that in Nigeria, broad money supply has minimal impact on manufacturing productivity, but manufacturing sector loans and foreign direct investment had a big impact.

Bernard and Adenuga (2016) investigated the association between economic changes and manufacturing sector performance in Nigeria from 1981 to 2009 using the Ordinary Least Squares (OLS) approach. The exchange rate, electric power consumption, and government capital spending all show unilateral relationships, according to the data. In effect, the exchange rate has a direct and considerable impact on manufacturing production, whereas the consumption of electric power has an indirect and significant impact.

Ifuero and Chijuka (2014) examined the impact of macroeconomic variables on bank profitability in Nigeria using annual data from 1990 to 2013. The variables studied were GDP, interest rate (INTR), and inflation (INFR) on return on equity (ROE), which is a proxy for profitability, and the analytical tool was Pooled Ordinary least square method. Gross domestic product (GDP) and return on equity (ROE) have a positive relationship, according to the studies (ROE). Return on equity (ROE) was found to have a negative relationship with the interest rate and inflation rate; the gross domestic product has a significant positive effect on return on equity (ROE), whereas the interest rate has a significant negative effect on return on equity (ROE), but inflation was not significant at all levels of significance. 
From 2005 to 2015, Ali and Bilal (2018) used multiple regression analysis to look into the factors that influenced the financial performance of Jordanian manufacturing industrial companies. Return on assets is favorably related to liquidity, profitability, and revenue, according to the study (ROA). It also has a negative relationship with the variables of leverage and company size. Furthermore, the regression findings demonstrated that all variables have a significant impact on the financial performance of Jordanian manufacturing industry businesses.

Multiple regression techniques were utilized by Lasisi, Dikki, and Okpanachi (2018) to analyze the factors that influenced the profitability of listed agricultural enterprises in Nigeria from 2008 to 2016. According to the findings, liquidity and sales growth have a positive and significant impact on profitability (ROE), whereas leverage has a negative and significant impact on profitability, and operating expense efficiency has a negligible negative impact on profitability of Nigerian listed agricultural companies.

Inyiama and Ozouli (2014) studied the connections between the foreign exchange rate and financial performance metrics in the Nigerian beer industry between 2000 and 2013. They discovered that earnings per share has a short-term negative and insignificant effect, whereas stock prices, net asset value per share, and price-earnings ratio are positively and insignificantly related to the foreign exchange rate in the short run, using Granger Causality, 2-step cointegration, Engle and Granger's Error Correction Model, and correlation analysis procedures. They also discovered that the exchange rate has a long-run negative and negligible relationship with all of the variables, with unidirectional causality connecting profits per share to exchange rate and exchange variations rate to net asset value per share.

Samiloglu, Oztop, and Kahraman (2017) investigated the drivers of business financial performance on the Istanbul stock exchange from 2006 to 2015. (BIST). The panel regression study found that ROA has a strong and negative relationship with the price-to-earnings (PE) ratio, earnings per share (EPS), and dividend yield (DY), however ROA had no significant link with the price-to-book ratio (PB). Furthermore, there is a strong and negative relationship between (ROE) and (ROE) (EPS). Finally, EPS, PB, and DY all have a significant and positive relationship with ROE.

From 2006 to 2015, Combey and Togbenou (2017) examined the short- and long-run relationship between three main macroeconomic indicators (GDP growth, real effective exchange rate, and inflation) and banking sector profitability (measured by return on assets and return on equity) in Togo using the Pool Mean Group estimator. In the short run, banks' return on assets and return on equity are unconnected to macroeconomic variables, according to the findings. Bank capital to assets ratio and bank size, on the other hand, have a positive impact on banks' return on assets, whilst bank capital to assets ratio has a negative impact on banks' return on equity. Real GDP growth and the real effective exchange rate, on the other hand, have a negative and statistically significant impact on banks' return on assets in the long run, whereas inflation has no such impact. In terms of a bank's return on equity, evidence suggests that real GDP growth, real effective exchange rate, and inflation have a negative impact in the long run. 
Kanwal and Nadeem (2013) looked at the impact of macroeconomic variables on the profitability of Pakistan's public limited commercial banks from 2001 to 2011. Using the Pooled Ordinary Least Square (POLS) method, the effect of three major external factors: inflation rate, real gross domestic product (GDP), and real interest rate on profitability indicators such as return on assets (ROA), return on equity (ROE), and equity multiplier (EM) ratios was investigated in three separate models. The real interest rate has a substantial positive relationship with ROA, ROE, and EM, according to the statistics. Real GDP was found to have a minor positive impact on ROA but a minor negative impact on ROE and EM once more. All three profitability metrics, on the other hand, have a negative association with the rate of inflation. The macroeconomic characteristics chosen have been found to have a small impact on commercial bank earnings in general.

Ugwu (2017) looked at the impact of exchange rate fluctuations on the performance of Nigerian manufacturing firms (1986 to 2016). The researchers employed an Ordinary Least Squares-based multivariate regression method. However, erroneous estimations were ruled out using the ADF unit root and Johansen cointegration tests. The outcomes of the study showed that changes in exchange rates had a statistically significant impact on the profitability of Nigerian manufacturing firms.

In Nigeria, Ogunbiyi and Ihejirika (2014) looked into how interest rates effect deposit money bank profitability. The data was acquired from the Central Bank of Nigeria (CBN) Statistical Bulletins and yearly reports, as well as World Bank Global Financial Development Data, over a thirteen-year period, from 1999 to 2012. Multivariate regression analysis, Augmented Dickey, and the Fuller unit root test were used to examine the data. The maximum lending rate, real interest rate, and savings deposit rate all have negative and signifficant effects on the profitability of Nigerian deposit money banks, according to the findings, as measured by return on assets at the $5 \%$ level of significance. The study also revealed that the real interest rate has a negative and significant relationship with the Return on Equity of Nigerian money deposit banks at the $8 \%$ level of significance. The study, on the other hand, found no link between interest rate factors and Nigerian Deposit Money Banks' Net Interest Margin.

Using the Engle and Granger, Johansen cointegration test, and Error correction mechanism, Okoye and Clement (2015) evaluated the impact of finance and macroeconomic variables on manufacturing capacity utilization in Nigeria from 1975 to 2012. The endogenous and exogenous variables were shown to be co-integrated using the Granger and Johansen cointegration test. According to ECM, the model responds slowly to short-term disequilibrium, and shocks are the primary rate of variances in industrial capacity utilization in Nigeria. Furthermore, EXR, INT, and TOT all contribute significantly but negatively to variances in manufacturing capacity utilization, whereas IFR, external reserve, and trade openness have no meaningful impact in Nigeria.

Dewi, Soei, and Surjoko explored the impact of macroeconomic conditions on a firm's profitability (2019). The data was evaluated using multiple regression methods and the t-test, and the results revealed that the ROA ratio is influenced by all independent variables. Only 
the level of GDP has a substantial impact on company profitability, according to a T-test, while inflation, unemployment, and the exchange rate have no rate.

From 1980 to 2016, Ditimi, Sunday, Emma-Ebere, and Onyedikachi (2018) studied the dynamic interaction between macroeconomic fundamentals and stock prices in Nigeria using a co-integration test and an error correction method. The findings revealed a long-term association between macroeconomic fundamentals and stock prices in Nigeria, but in the short run, past money supply and interest rate values were found to have a substantial effect on stock prices. Furthermore, the recent stock market return has had a significant impact on current stock values. According to the data, the natural logarithm of real gross domestic product is a leading indicator that increases stock prices in the long and short run.

Kabeer, Iqbal, Najaf, and Najaf (2016) employed Ordinary Least Square (OLS) to study the influence of macroeconomic factors on capital market performance in Pakistan. Inflation, the exchange rate, and foreign direct investment all had a considerable negative impact on the KSE dependent variable, but only a slight negative impact on the KSE independent variable.

Sufian (2011) looked how bank-specific and macroeconomic variables influenced the performance of the Korean banking system before to and following the Asian financial crisis. A total of 251 bank year records from 11 commercial banks were used and tested using panel fixed and random effect regression techniques between 1993 and 2003. According to the findings, inflation has a positive relationship with banks' return on assets.

Naser and Abdollah (2015) investigated the impact of internal and external factors, as well as macroeconomic variables, on the profitability of twenty-six (26) Pakistani Deposit Money Banks from 2008 to 2012. They used panel data analysis with 130 observations to investigate the impact of internal and external factors, as well as macroeconomic variables, on the profitability of twenty-six (26) Pakistani Deposit Money Banks from 2008 to 2012. Inflation and the profitability of Pakistani Deposit Money Banks have a positive relationship, according to the findings.

Hassan (2016) used the Ordinary Least Square (OLS) and multiple regression techniques to investigate the impact of interest rates on commercial bank deposits in Nigeria. The study employed secondary data from the Central Bank of Nigeria statistical bulletin and the National Bureau of Statistics between 2000 and 2013. Interest rates have a negative relationship with commercial bank deposits, meaning that interest rates are not to blame for client deposits in Nigerian commercial banks, according to the findings.

From 1995 to 2010, Akabom-Ita (2012) examined the impact of interest rates on the net assets of multinational firms in Nigeria using regression analysis. The information was acquired from secondary sources, and the findings demonstrated that an increase in interest rates is followed by an increase in net assets.

Bhattarai (2018) investigated at the impact of bank-specific and macroeconomic variables on the performance of Nepalese commercial banks from 2011 to 2016. The data was analyzed using regression models, and the findings revealed that in Nepal, commercial asset profitability is primarily influenced by cost per loan asset, that macroeconomic variables are 
not significant, and that there is no evidence that external forces have an impact on bank performance.

Musah, Anokye, and Gakpetor investigated the impact of interest rate spread on bank profitability in Ghana (2018). Regression research found a positive and statistically significant relationship between interest rate spread and bank profitability in Ghana.

Owusu-Antwi, Banerjee, and Antwi (2017) employed ordinary least square regression to investigate interest rate spreads and profitability of commercial banks in Ghana. Interest rate spread has a positive impact on commercial bank profitability in Ghana, according to the findings, but the relationship is statistically negligible. Bank profitability and interest margin are also linked.

Enyioko (2012) investigated the impact of interest rate policy on deposit money bank performance in Nigeria using regression and error correction techniques. The findings showed that interest rate strategies benefited banks' overall performance, especially in terms of Return on Assets (ROA).

The Augmented Dickey-Fuller technique and the Granger Causality test were used by Umaru and Zabairu (2012) to investigate the effect of inflation on Nigerian economic growth and development from 1970 to 2010. According to the findings, all of the variables in the model are stationary, and GDP causes inflation rather than inflation driving GDP. Inflation also aided economic growth by increasing productivity and output, as well as the evolution of total factor productivity.

Falaye, Eseyin, Otekunri, Asamu, Ogunlade, Egbide, Rasak, Moyinoluwa, and Eluyela (2019) investigated at the impact of exchange rates on the performance of the Nigerian manufacturing sector, using exchange rates, inflation rates, capacity utilization rates, manufacturing sector foreign direct investments, and imports as independent variables. Between 1990 and 2014, it took occurred. Analytical tools included the ADF unit root test, Granger causality test, Johansen co-integration test, and Error Correction Mechanism. Following that, the study's findings revealed that the Naira's depreciation has a negative impact on Nigeria's manufacturing sector. In more concrete terms, it was discovered that the exchange rate has a negative and significant relationship with the sector's performance, as well as a causal and long-relationship relationship. Furthermore, empiricial evidence reveals that capacity utilization (CUR) and inflation rates (INF) have a positive significant relationship with sector performance, whereas manufacturing foreign direct investment (MFDI), exchange rates, and imports (IMP) have a negative significant relationship.

Over a 25-year period, Adebanjo, Oluwasegun, Adegbola, Festus, Peter, Ben-Caleb, Bamisele, NIyi-Oyebanji, and Damilola (2019) examined at the impact of exchange rates on Nigeria's manufacturing sector performance. The Granger Causality and Error Correction Model (ECM) Mechanism, as well as basic diagnostic techniques like the Unit Root Test and the Johansen Co-integration Test, were applied by the researchers. The findings revealed that depreciation of the Naira has a negative significant relationship, a long-run relationship, and a causal relationship with the performance of the Nigerian manufacturing sector. Exchange 
rates, imports (IMP), and manufacturing foreign direct investment (MFDI) show a negative substantial relationship with the performance of the Nigerian manufacturing sector.

Agubata and Odubuasi (2018) examined the effect of exchange rate fluctuations on the financial performance of Nigerian businesses. The study was carried out between 2005 and 2014. An ex post facto study approach and a variety of regression analysis methodologies were used to analyze the data. The findings revealed that exchange rates and inflation rates had a positive effect on the Return on Assets (ROA) and Return on Equity (ROE) of the selected enterprises (ROE). According to the findings, interest rates have a detrimental impact on manufacturing enterprises' Return on Assets and Return on Equity in Nigeria. In the meantime, none of these ramifications were notable.

Tams-Alasia, Olokoyo, Okoye, and Ejemeyovwi (2018) investigated the impact of exchange rate deregulation on manufacturing output performance in Nigeria from 1980 to 2016. The direction of causation between the variables was determined using the granger causality test. To see if there was a long-run relationship between the exchange rate and manufacturing output, the Johansen and Juselius normalized cointegration technique was applied. The error correcting process was also used to calculate the model's velocity (speed) of adjustment to the short-run disequilibrium scenario (ECM). The study found that, in the long run, the exchange rate has no significant positive effect on manufacturing industry production. The unidirectional causal impact of exchange rate on manufacturing production was established using the pairs granger causality test.

Williams (2018) looked at the impact of exchange rate fluctuations on a company's performance in Nigeria. The study's major purpose was to use empirical research to investigate into the impact of exchange rate variations on Return on Investment. The study used descriptive and ordinary least square methodologies and spanned the years 2012 to 2016 . The exchange rate has a substantial impact on Return on Investment, as most banks engage in exchange rate transactions, as the study shows.

From 1981 to 2016, Orji, Ogbuabor, and Okeke (2018) examined the impact of exchange rate $(\mathrm{EXCH})$ fluctuations on the Nigerian manufacturing sector using annual time series data. The Ordinary Least Square (OLS) estimate technique was used to investigate the exchange rate (EXCH), manufacturing GDP (MGDP), foreign direct investment (FDI), government capital expenditure variables, private sector credit, and import value. The findings show that fluctuations in the EXCH have a major impact on the performance of Nigeria's manufacturing industries. MGDP and government capital expenditure (GCEXP) were all favorably connected to $\mathrm{EXCH}$, imports, and FDI, while credit to the private sector was adversely related.

Segun investigated the impact of the exchange rate on Nigerian industrial output (2018). Multiple econometric methodologies were used on time-series data from 1986 to 2016, including the Augmented Dickey-Fuller unit root test, the Box Jenkins O.L.S methodology, and the Chow breakpoint test. Although there is no long-run relationship between exchange rate and industrial output in Nigeria, the Box Jenkins O.L.S results reveal that exchange rate has a positive and significant effect on industrial output. Furthermore, the Chow breakpoint 
test suggests that a fundamental shift in the pattern and direction of Nigeria's exchange rate and industrial output happened from the start of the fourth republic in 1999.

\section{3. methodology}

\subsection{Research Design}

The study is a "after-the-fact" study of the impact of the independent variables on the dependent variable. As a result, the study was conducted after the fact. Annual time series secondary data were taken from the Central Bank of Nigeria $(\mathrm{CBN})$ statistical bulletin, as well as annual reports and financial statements of the selected firms, for the study periods. Numerical data was gathered from journal articles, newspapers, textbooks, and other published and unpublished sources.

\subsection{Model Specification}

The model for this study follows the work of Okoye and Clement (2015). It is a Classical Linear Regression Model (CLRM), and particularly, the ordinary least squares regression technique. The choice of least squares technique is to minimize the error sum of squares, maintaining the property of the best unbiased linear estimator.

The model did not undermine the assumption that: $Y \sim N\left(\theta, \sigma^{2}\right)-\quad-\quad-\quad$ (3.1)

Where $\mathrm{Y}$ is the Dependent (or Response) variable; $\theta$ is the constant or intercept of the regression model, $\sigma^{2}$ is the variances and covariances of the random term.

Explicitly, the model is specified thus:

$$
Y_{i j}=\beta_{\mathrm{o}}+\beta_{1} \mathrm{X}_{1 \mathrm{ij}}+\beta_{2} \mathrm{X}_{2 \mathrm{ij}}+\beta_{3} \mathrm{X}_{3 \mathrm{ij}}+\beta_{4} \mathrm{X}_{4 \mathrm{ij}}+\beta_{5} \mathrm{X}_{5 \mathrm{ij}}+\ldots+\beta_{\mathrm{k}} \mathrm{X}_{\mathrm{kij}}+\mu_{\mathrm{ij}} \quad-
$$

Where;

$\mathrm{Y}$ is the estimator for Return on Assets while $\mathrm{X}_{1}, \mathrm{X}_{2}, \mathrm{X}_{3}, \mathrm{X}_{4}$, and $\mathrm{X}_{5}$ are random variables representing the independent variables under investigation, $\beta_{j}^{\prime s}$ are coefficients of $X_{i}^{\prime s}$ in the model. Such that,

$$
\begin{aligned}
& R O A_{t}=\beta_{\mathrm{o}}+\beta_{1} \mathrm{EXCH}_{\mathrm{t}}+\beta_{2} \mathrm{INTR}_{\mathrm{t}}+\beta_{3} \mathrm{INFR}_{\mathrm{t}}+\beta_{4} \mathrm{EXTD}_{\mathrm{t}}+\beta_{5} \mathrm{OPN}_{\mathrm{t}}+\mu_{\mathrm{ij}}- \\
& R O A_{t}=\text { Return on Assets at time t, (Dependent variable). } \\
& \mathrm{EXCH}_{t}=\text { Exchange rate at time t, (Independent variable). } \\
& \text { INTR }_{t}=\text { Interest rate at time t, (Independent variable). } \\
& I_{N F R}=\text { Inflation rate at time } t \text {, (Independent variable). } \\
& \text { EXTD }_{t}=\text { External Debt at time t, (Independent variable). } \\
& \mathrm{OPN}_{t}=\text { Trade Openness at time t, (Independent variable). } \\
& \beta_{o} \quad=\text { Constant }
\end{aligned}
$$


$\mu_{\mathrm{t}} \quad=\quad$ Random error associated with the model.

$\beta_{1}, \beta_{2}, \beta_{3}, \beta_{4}$ and $\beta_{5}$ are the regression coefficients of the respective independent variables.

\subsection{Description of Model Variables}

Return on Assets (ROA): This is an accounting-based measure of a company's ability to profit from its total assets. It shows how lucrative a company is in company to its total assets, indicating how successfully it utilizes its assets. It is the ratio of a company's annual net profit to its total assets, usually represented as a percentage.

Exchange Rate (EXCR): This is the exchange rate between two currencies at a certain point in time, or the value of one nation's currency in terms of another nation's currency.

Trade Openness (OPN): This metric assesses a country's international competitiveness in the global market. The sum of imports and exports over GDP was used to calculate trade openness in this study.

Interest Rate (INT): This is the cost of doing business with money. It is the expense of borrowing money from a lender that is referred to as the opportunity cost. It can also be seen of as a return paid to the provider who provided the financial resources. In most cases, the interest rate is stated as a percentage.

External Debt (EXTD): This is money that has been borrowed from a source outside the country. It can be provided by foreign commercial banks, international financial institutions including the International Monetary Fund (IMF), the World Bank, and the African Development Bank (ADB), as well as foreign governments.

Inflation Rate (INFL): This is a persistent rise in the general price level of a broad spectrum of goods and services in a country over a one-year period. It's measured in percentages.

\subsection{Methods of Data Analysis}

Descriptive statistics and ordinary least squares regression analysis were used to analyze the data. The descriptive statistics provide an empirical description of the variables under examination, whereas the regression analysis analyzes the explanatory variable's effect on the answer variable.

\section{Decision Rule}

Reject the null hypothesis (Ho) if the p-value is less than or equal to 0.05 , otherwise do not reject.

\subsubsection{Diagnostic Tests}

To summarize the level of symmetry and tail thickness of the data series distribution, the skewness and kurtosis statistics were used. The skewness and kurtosis of $\mathrm{X}$ are defined as follows: 
$\mathrm{S}(\mathrm{x})=E\left[\frac{\left(X-\mu_{x}\right)^{3}}{\sigma_{x}^{3}}\right]$ which implies that $\hat{S}_{(x)}=\frac{1}{(T-1) \hat{\sigma}_{x}^{3}} \sum_{t=1}^{T}\left(X_{i}-\hat{\mu}_{x}\right)^{3}$

Also, $\mathrm{S}(\mathrm{x}) \sim \mathrm{N}\left(0, \frac{6}{T}\right)$

$\mathrm{K}(\mathrm{x})=E\left[\frac{\left(X-\mu_{x}\right)^{4}}{\sigma_{x}^{4}}\right]$ which implies that $\widehat{K}_{(x)}=\frac{1}{(T-1) \hat{\sigma}_{x}^{4}} \sum_{t=1}^{T}\left(X_{i}-\hat{\mu}_{x}\right)^{4}$

The $\mathrm{K}(\mathrm{x}) \sim \mathrm{N}\left(0, \frac{24}{T}\right)$

Where $\mathrm{X}$ stands for observations for the period, $\mu_{x}$ is the mean of series of the observations, $\sigma_{x}^{3}$ and $\sigma_{x}^{4}$ stands for the variance of $\mathrm{X}$ from the mean.

The amount $\mathrm{K}(\mathrm{x})-3$ is known as the excess kurtosis since $\mathrm{K}(\mathrm{x})=3$ for a normal distribution. In a normal random variable, excess kurtosis is nil. A distribution with positive excess kurtosis is considered to have heavy tails, indicating it puts more emphasis on the support's tails than a normal distribution. This indicates that a random sample drawn from such a distribution is more likely to contain extreme values. This type of distribution is known as leptokurtic. In contrast, a distribution with negative excess kurtosis has short tails and is platykurtic.

Jarque and Bera (1987) integrated the two previous tests to arrive at the following conclusion:

$\mathrm{JB}=\frac{\hat{S}^{2}(r)}{6 / T}+\frac{(\widehat{K}(r)-3)^{2}}{24 / T}$ which is asymptotically distributed as a Chi-squared random variable with 2-degrees of freedom. In this test, one rejects Ho of normality if the p-value of the JB statistic is less than the significance level.

\section{Data Presentation and Analysis}

Table 4.1 presents the annual time data of Return on Assets (ROA) of the selected manufacturing firms for the period under review.

Table 4.1 Annual data of ROA from 2008-2018

\begin{tabular}{llllll}
\hline Year & GSK & NEIMETH & MAY \& BAKER & PHARMA-DEKO & FIDSON \\
\hline $\mathbf{2 0 0 8}$ & 14.22 & -17.02 & 3.54 & -39.11 & 6.01 \\
$\mathbf{2 0 0 9}$ & 14.09 & -15.76 & 3.77 & -50.17 & 5.97 \\
$\mathbf{2 0 1 0}$ & 13.42 & -4.53 & 2.83 & -18.89 & 5.90 \\
$\mathbf{2 0 1 1}$ & 12.79 & 3.69 & 3.16 & 2.98 & 3.31 \\
$\mathbf{2 0 1 2}$ & 12.96 & -2.07 & 0.94 & 26.63 & 1.92 \\
$\mathbf{2 0 1 3}$ & 11.14 & 4.52 & -1.26 & -8.88 & 1.27 \\
$\mathbf{2 0 1 4}$ & 6.60 & -8.21 & 0.78 & 3.56 & 4.01 \\
$\mathbf{2 0 1 5}$ & 2.79 & -15.26 & 0.83 & 25.65 & 4.52 \\
$\mathbf{2 0 1 6}$ & 8.44 & 2.42 & -0.48 & -9.41 & 0.75 \\
$\mathbf{2 0 1 7}$ & 1.84 & -18.04 & 4.01 & 0.56 & 6.08 \\
$\mathbf{2 0 1 8}$ & 2.05 & 5.21 & 7.58 & 3.27 & 2.08 \\
\hline
\end{tabular}




\section{Macrothink Institute}

Source: Author's computation from the Annual accounts \& financial statements of the firms

Computational formula: $\quad \mathrm{ROA}=$ Return on Asset $=\frac{\text { Profit after Tax }}{\text { Total Assets }} \times 100$

Table 4.2 Annualized time series data of the selected macroeconomic variables (2008-2018)

\begin{tabular}{cccccc}
\hline YEARS & INT (\%) & EXCR (N1/USD) & OPN & EXTD (N'B) & INFL (\%) \\
\hline $\mathbf{2 0 0 8}$ & 15.14 & 118.5669 & 0.408114 & 523.25 & 11.6 \\
$\mathbf{2 0 0 9}$ & 18.99 & 148.8802 & 0.318094 & 590.44 & 12.4 \\
$\mathbf{2 0 1 0}$ & 17.59 & 150.2980 & 0.369431 & 689.84 & 13.3 \\
$\mathbf{2 0 1 1}$ & 16.02 & 153.8616 & 0.416519 & 896.85 & 10.9 \\
$\mathbf{2 0 1 2}$ & 16.79 & 157.4994 & 0.347295 & $1,026.90$ & 12.2 \\
$\mathbf{2 0 1 3}$ & 16.72 & 157.3112 & 0.308411 & $1,387.33$ & 8.5 \\
$\mathbf{2 0 1 4}$ & 16.55 & 158.5526 & 0.263907 & $1,631.52$ & 8.0 \\
$\mathbf{2 0 1 5}$ & 16.85 & 193.2792 & 0.211602 & $2,111.53$ & 9.5 \\
$\mathbf{2 0 1 6}$ & 16.87 & 253.4923 & 0.180472 & $3,478.92$ & 15.7 \\
$\mathbf{2 0 1 7}$ & 17.58 & 305.7901 & 0.218034 & $5,787.51$ & 16.5 \\
$\mathbf{2 0 1 8}$ & 16.90 & 306.0753 & 0.231072 & $5,901.20$ & 12.1 \\
\hline
\end{tabular}

Source: CBN Statistical Bulletin 2019

\subsection{Data Analysis}

Data analysis includes descriptive, diagnostic, and inferential statistics. Tables 4.3 and 4.4 show descriptive statistics, figure 1 shows the results of the diagnostic test, and tables 4.5 shows the results of inferential (especially regression) analysis.

Table 4.3 Descriptive Statistics

\begin{tabular}{lcccccc}
\hline & ROA & EXCR & INT & INFL & EXTD & OPN \\
\hline Mean & 0.709091 & 191.2370 & 16.90909 & 11.88182 & 2184.117 & 0.297541 \\
Median & 2.980000 & 157.4994 & 16.85000 & 12.10000 & 1387.330 & 0.308411 \\
Maximum & 26.63000 & 306.0753 & 18.99000 & 16.50000 & 5901.200 & 0.416519 \\
Minimum & -50.17000 & 118.5669 & 15.14000 & 8.000000 & 523.2500 & 0.180472 \\
Std. Dev. & 12.68462 & 63.60727 & 0.930357 & 2.574022 & 1923.310 & 0.079073 \\
Skewness & -1.641389 & 0.931756 & 0.386867 & 0.249533 & 1.103207 & 0.088330 \\
Kurtosis & 7.829927 & 2.308927 & 3.726711 & 2.282589 & 2.663006 & 1.654913 \\
Jarque-Bera & 78.15688 & 9.052671 & 2.582188 & 1.750249 & 11.41669 & 4.217737 \\
Probability & 0.000000 & 0.010820 & 0.274970 & 0.416810 & 0.003318 & 0.121375 \\
Sum & 39.00000 & 10518.03 & 930.0000 & 653.5000 & 120126.4 & 16.36475 \\
Sum Sq. Dev & 8688.576 & 218477.8 & 46.74045 & 357.7818 & $2.00 \mathrm{E}+08$ & 0.337639 \\
Observations & 55 & 55 & 55 & 55 & 55 & 55 \\
\hline
\end{tabular}

\section{Source: Author's Eviews 10 output}

The behavior of the data series over period is indicated in table 4.3 by the descriptive and diagnostic test results. Interest and inflation rates were stable (low standard deviation), 


\section{Macrothink}

whereas the ROA, EXCR, EXTD, and OPN series were volatile. The data series EXCR, INT, INFL, EXTD, and OPN were clustered on the left tail of the normal distribution curve, while the data series EXCR, INT, INFL, EXTD, and OPN were clustered on the right tail. Within control, however, the Kurtosis statistics reveal a positive excess kurtosis in a series of ROA, INFL, EXCR, and OPN.

The probability value of the Jarque-Bera (JB) statistics for Return on Assets (ROA), Exchange Rate (EXCR), and External Debt (EXTD) was less than the significance level (0.05), indicating that the series of ROA, EXCR, and EXTD were not normally distributed over the time period under consideration. The series of INT, INFL, and OPN (with p-values > 0.05 ) on the other hand, follows a normal distribution.

Table 4.4 Empirical Result of the relationship between Return on Assets and some selected macroeconomic variables in Nigeria

Covariance Analysis: Ordinary

Date: 03/20/20 Time: 00:02

Sample: 20082018

Included observations: 41

Balances sample

(listwise missing value deletion)

Correlation

t-Statistic

\begin{tabular}{|c|c|c|c|c|c|c|}
\hline Probability & LNROA & LNEXCR & LNINT & LNINFL & LNEXTD & LNOPN \\
\hline \multirow[t]{3}{*}{ LNROA } & 1.000000 & & & & & \\
\hline & ----- & & & & & \\
\hline & ----- & & & & & \\
\hline \multirow[t]{3}{*}{ LNEXCR } & -0.276160 & 1.000000 & & & & \\
\hline & -1.794401 & ----- & & & & \\
\hline & 0.0805 & ----- & & & & \\
\hline \multirow[t]{3}{*}{ LNINT } & -0.011457 & 0.307192 & 1.000000 & & & \\
\hline & -0.071556 & 2.015888 & ----- & & & \\
\hline & 0.9433 & 0.0507 & ----- & & & \\
\hline \multirow[t]{2}{*}{ LNINFL } & -0.063883 & 0.496821 & 0.343059 & 1.000000 & & \\
\hline & -0.399768 & 3.575085 & 2.280820 & ----- & & \\
\hline
\end{tabular}




\begin{tabular}{l|rrrrrr} 
LNEXTD & -0.311203 & 0.965444 & 0.166577 & 0.303733 & 1.000000 & \\
& -2.045010 & 23.13492 & 1.055015 & 1.990869 & ----- & \\
0.0476 & 0.0000 & 0.2979 & 0.0535 & ---- & \\
LNOPN & & & & & & \\
& 0.275732 & -0.795373 & -0.333505 & -0.212503 & -0.840188 & 1.000000 \\
1.791388 & -8.194907 & -2.209219 & -1.358097 & -9.675486 & ----- \\
& 0.0810 & 0.0000 & 0.0331 & 0.1822 & 0.0000 & ----- \\
\hline
\end{tabular}

\section{Source: Author's Eviews 10.0 Result}

The Pearson correlation test result as shown in table 4.4 shows a positive relationship between trade openness (LNOPN) and Return on Asset (LNROA) of Healthcare manufacturing firms in Nigeria. Meanwhile, there were negative relationships between exchange rate (LNEXCR), interest rate (LNINT), inflation rate (LNINFL), and external debt (LNEXTD) to Return on Asset (LNROA) of the selected firms over the period. Also, from the correlation result, a high coefficient was shown between trade openiness (LNOPN) and exchange rate, external debt (LNEXTD) and exchange rate (LNEXCR) and between trade openness (LNOPN) and external debt (LNEXTD), which is an indication of a multicollinearity problem. Hence, the researcher employed the Fully Modified Ordinary Least Squares (FMOLS) panel cointegrating regression technique to ascertain the effects of the explanatory variables on the response variable. The result is as shown in table 4.5 below.

Table 4.5 Cointegrating Regression Result of effects of the selected macroeconomic variables on Return on Assets (ROA) of the Healthcare manufacturing firms

Dependent Variable: LNROA

Method: Panel Fully Modified Least Squares (FMOLS)

Sample (adjusted): 20092018

Periods included: 10

Cross-sections included: 4

Total panel (balanced) observations: 34

Panel method: Pooled estimation

Cointegrating equation deterministic: $\mathrm{C}$

Coefficient covariance computed using default method

Long-run covariance estimates (Bartlett kernel, Newey-West fixed bandwidth)

\begin{tabular}{ccccr}
\hline \hline Variable & Coefficient & Std. Error & t-Statistic & Prob. \\
\hline \hline LNEXCR & -2.840031 & 1.169481 & -2.322044 & 0.0173 \\
LNINT & -0.252066 & 0.917652 & -0.280324 & 0.7811 \\
LNINFL & 1.285022 & 0.421165 & 3.296603 & 0.0125
\end{tabular}




\begin{tabular}{lcccr} 
LNEXTD & -0.089132 & 0.350888 & -0.251045 & 0.7943 \\
LNOPN & -0.170522 & 0.221083 & -0.731809 & 0.4598 \\
\hline quared & 0.739452 & Mean dependent var & & 2.039433 \\
usted R-squared & 0.693386 & S.D. dependent var & & 0.708121 \\
of regression & 0.378859 & Sum squared resid & & 5.412510 \\
g-run variance & 0.025884 & & &
\end{tabular}

Source: Author's Eviews 10.0 Output

From the Fully Modified Ordinary Least Squares (FMOLS) panel cointegrating regression result as presented in table 4.5 above, only inflation rate exerts a positive influence on Return on Assets of the Healthcare manufacturing firms in Nigeria. The exchange rate, interest rate, external debt and trade openness have a negative effect on the Return of Assets of the firms. The explanatory power of the model as estimated by the coefficient of multiple determination $\left(\mathrm{R}^{2}\right)$ was 0.739 indicating that the model is a good one as about $73.9 \%$ of the total variations in Return on Assets (ROA) of the selected firms are attributable to fluctuations in the macroeconomic variables in Nigeria.

\subsection{Test of Hypotheses}

Hypotheses One

Ho: : Exchange Rate does not have a significant effect on ROA of Healthcare Manufacturing Firms in Nigeria.

Decision Criteria: Accept Null Hypotheses if P-value $>0.05$ otherwise reject Null Hypotheses if $\mathrm{P}$-value $<0.05$

Result; P-value $=0.0173 ; 0.0173<0.05$

Regarding table 4.5, the exchange rate has a negative and significant effect on the Return on assets of Healthcare manufacturing firms in Nigeria. A unit increase in the naira exchange rate decreases the Return on Assets of a Healthcare manufacturing firm by 2.81 . The null hypothesis is therefore rejected.

Hypotheses Two

Ho2: Interest rate does not have a significant effect on Return on Assets (ROA) of Healthcare manufacturing firms in Nigeria.

Decision Criteria: Accept Null Hypotheses if P-value $>0.05$ otherwise reject Null Hypotheses if $\mathrm{P}$-value $<0.05$

Result; P-value $=0.7811 ; 0.7811>0.05$

As shown in table 4.5 , interest rate with a coefficient value of -0.25 , $t$-statistics value -0.28 and associated probability value of $0.7811>0.05$ has a negative and insignificant effect on the Return on assets of Healthcare manufacturing firms in Nigeria. Particularly, a unit increase in 
interest rate decreases the Return on Asset of a Healthcare manufacturing firm by 0.25 . The null hypothesis as stated in hypothesis two is therefore upheld.

Hypothesis Three

Ho3: Inflation rates does not have a significant effect on the Return on Assets (ROA) of healthcare manufacturing firms in Nigeria.

Decision Criteria: Accept Null Hypotheses if P-value $>0.05$ otherwise reject Null Hypotheses if $\mathrm{P}$-value $<0.05$

Result: P-value $=0.0125 ; 0.0125<0.05$

Inflation rate with a coefficient value of 1.29 , t-statistics value 3.30 and associated Probability value of $0.0125<0.05$, we reject the null hypothesis and conclude that inflation rate has a significant effect on ROA of Healthcare manufacturing firms in Nigeria, hence a unit increase in inflation rate increases ROA by 1.29 .

Hypotheses Four

Ho4: External debt does not have a significant effect on the Return on Assets (ROA) of healthcare manufacturing firms in Nigeria.

Decision Rule: Accept Null Hypotheses if P-value $>0.05$ otherwise reject Null Hypotheses if P-value $<0.05$

Result: P-value $=0.7943 ; 0.7943>0.05$

External debt with a coefficient value of -0.09 , t-statistic value -0.25 and associated Probability value of $0.7943>0.05$ has a negative and insignificant effect on the return on assets of healthcare manufacturing firms in Nigeria, we accept the null hypothesis and conclude that External debt does not have a significant effect on return on asset of healthcare manufacturing firms in Nigeria, a unit increase in external debt decreases the return on asset of healthcare manufacturing firm by 0.09 .

Hypotheses Five

Ho5: Trade openness does not have a significant effect on the Return on Assets (ROA) of healthcare manufacturing firms in Nigeria.

Decision Rule: Accept Null Hypotheses if P-value $>0.05$ otherwise reject Null Hypotheses if $\mathrm{P}$-value $<0.05$.

Result: P-value $=0.4598 ; 0.4598>0.05$

The empirical result with a coefficient value of -0.17 , t-statistic value $-0,73$, associated probability of $0.4598>0.05$ shows that Return on Assets of Healthcare manufacturing firms is negatively and insignificantly influenced by the volume of trade openness in Nigeria, a unit increase in the level of trade openness decrease the Return on Asset of Healthcare Manufacturing firm by o.17, we accept the null hypothesis and conclude that Trade openness 
does not have a significant effect with Return on Assets (ROA) of healthicare manufacturing firms in Nigeria.

\subsection{Discussion of Results}

From the first objective, it was ascertained that a high exchange rate is detrimental to the financial performance of Nigerian healthcare manufacturing firms. It has a strong negative impact on the Return on Assets of the selected Nigerian firms. This finding is in work with Okoye and Clement's (2015), Kabeer et al's (2016), and Egbunike and Okerekeoti's study. Combey and Togbenou (2017), Bernard and Adenuga (2016), and Ugwu (2016) have all come to similar conclusions. It contradicts Dewi, Soei, and Surjoko's (2019) findings that the exchange rate has no substantial impact on firm ROA.

High loan rates are detrimental to the financial performance of Nigerian healthcare manufacturing companies, according to objective two. This is consistent with current economic situations and earlier research, such as Akabom-Ita (2012), Egbunike, and Okerekeoti (2018). It also backs up findings of Ifuero and Chijuka (2014), Ogunbiyi and Ihejirika (2014), and Okoye and Clement (2014). (2015). This result disagrees Kanwal and Nadeem (2013)'s findings, which were based on a study conducted in Pakistan. It also disagrees Ditimi et al's (2018) findings, among others.

The study discovered that a high inflation rate favors the growth of the industrial sector in Nigeria by measuring the effect of the inflation rate on the financial performance of Healthcare manufacturing firms in Nigeria. This result, however, is consistent with the findings of Naser and Abdollah (2015), Egbunike and Okerekeoti (2015), and Naser and Abdollah (2015). This result disagrees Kanwal and Nadeem (2013), Ifuero and Chijuka (2014), Kabeer et al (2016), Combey and Togbenou (2017), and Dewi, Soei, and Surjoko (2017) findings (2019).

The fourth hypothesis was tested, and it was discovered that a high level of external debt in Nigeria stifles the growth of healthcare manufacturing firms. This result was consistent with Okoye and Clement's findings (2015). As a result of the study's fifth objective, trade openness was found to be negatively connected with the financial performance of Nigerian healthcare manufacturing firms. This finding is consistent with Okoye and Clement's (2015) findings that trade openness has a negative and minor impact on manufacturing capacity utilization.

\section{Summary of Findings, Conclusion and Recommendations}

\subsection{Summary of Findings}

Evidence from this research work showed that:

i) The exchange rate has a significant negative effect on the financial performance of healthcare manufacturing firms in Nigeria.

ii) The interest rate has a negative and insignificant effect on the financial performance of healthcare manufacturing firms in Nigeria. 
iii) The inflation rate has a significant positive effect on the financilal performance of healthcare manufacturing firms in Nigeria.

iv) External debt has a negative and insignificant effect on the financial performance of healthcare manufacturing firms in Nigeria.

v) Trade openness has a negative and insignificant effect on the financial performance of healthcare manufacturing firms in Nigeria.

\subsection{Conclusion}

Having explored the nexus between key financial performance indicators and some selected macroeconomic variables in Nigeria with the help of fully modified ordinary least squares panel multiple regression analysis techniques, the big lesson from this study is that macroeconomic indices play significant roles in the financial position of Healthcare manufacturing firms in Nigeria.

\subsection{Recommendations}

Based on this research discovery, the following recommendations were made:

i) The exchange rate should be monitored while economic policy measures aimed at controlling the exchange rate in Nigeria should be established.

ii) Bank lending rate should be regulated and set to a rate favourable to the growth of Healthcare manufacturing companies in Nigeria.

iii) Efforts to maintain single-digit inflation should be intensified since it is favourable to the growth of manufacturing firms and the overall growth of the Nigerian economy.

iv) The federal government of Nigeria should work towards reducing their level of borrowing from foreign countries and international bodies since it negatively affects manufacturing firms' performance in Nigeria.

v) The volume of trade openness should be minimized to enhance the productivity of Healthcare manufacturing firms in Nigeria.

\section{References}

Adebanjo, J. F., Oluwasegun, E,. Adegbola, O., Festus, A., Peter, O., Ben-Caleb, E., Bamisele, R., Niyi-Oyebanji, M., \& Damilola, E. (2019). Impact of exchange rate on the Manufacturing sector in Nigeria, International Journal of Mechanical Engineering and Technology, 10(2), 1568-1583.

Agubata, S. N. \& Odubuasi, A. C. (2018). Effect of exchange rate fluctuations on the financial Performance of Nigeria manufacturing firms: Evidence from food, beverage and tobacco Sector. International Journal of Commerce and Management Research, 4(4), 56-61.

Akabom-Ita, A. (2012). Impact analysis of interest rate on the net assets of multinational businesses in Nigeria. Research Journal of Finance and Accounting, 3(7). 
Bernard, O. A., \& Adenuga, O. (2011).Impact of Economic Reforms on Performance of the Manufacturing Sector in Nigeria. Retrieved from http://ssrn.com/abstract=2717655

Bhattarai, B. P. (2018). Impact of Bank Specific and Macroeconomic Variables on Performance of Nepalese Commercial Banks.Global Review of Accounting and Finance, 9(1), 35-53.

Combey, A. \& Togbenou, A. (2017). The bank sector performance and macroeconomics environment: Empirical evidence in Togo. International Journal of Economics and Finance, 9(2). https://doi.org/10.5539/ijef.v9n2p180

Darfor J \& Agyapyong (2010) Effects of macro- economic variables on commercial banks a. stocks. Journal of Business Enterprise Development. ISSN 2026-500.

Dewi, V. I., Soei, C. T. L. \& Surjoko, F. O. (2019). Impact of macroeconomic factors on firm's profitability: Evidence from fast moving consumer good firms listed on Indonesian stock exchange. Academy of Accounting and Financial Studies Journal, 23(1), 1-6.

Ditimi, A. Sunday, K. Emma-Ebere \& Onyedikachi (2018). Dynamic interrelationship between macroeconomic fundamentals and stock prices in Nigeria.J Fin Mark, 2(1), 50-59.

Egbunike, C. F. \& Okerekeoti, C. U. (2018). Macroeconomic factors, firm characteristics andfinancial performance: A study of selected quoted manufacturingfirms in Nigeria. Asian Journal of Accounting Research, 1-14. https://doi.org/10.1108/AJAR-09-2018-0029

Enyioko, N. (2012). Impact of interest rate policy and performance deposit money banks in Nigeria. Global Journal of Management and Business Research, 12(21)

Falaye, A.J., Eseyin, O., Otekunrin, A., Asamu, F., Ogunlade, P., Egbide, B., Rasak, B., Moyinoluwa, N., \& Eluyela, D. (2019). Impact of exchange rate on the manufacturing sector in Nigeria. International Journal of Mechanical Engineering and Technology (IJMET), 10(2), $1568-1583$

Gikombo, E. M. \& Mbugua, D. (2018). Effect of select macro-economic variables on performance of listed commercial banks in Kenya.International Academic Journal of Economics and Finance, 3(1), 80-109.

Hassan, O. M. (2016). Effect of Interest Rate on Commercial Bank Deposits in Nigeria. American Academic Research Conference on Global Business, Economics, Finance and Social Sciences (AAR16 New York Conference), 1-17.

Ifuero, O. O. \& Chijuka, I. M. (2014). The impact of macroeconomic variables on the profitability of listed commercial banks in Nigeria.European Journal of Accounting Auditing and Finance Research, 2(10), 85-95.

Ijirshar, V. U., Joseph, F. \& Gadoo, M. (2016). The relationship between external debt and economic growth in Nigeria. International Journal of Economics \& Management Sciences, 6(1), 2-5. https://doi.org/10.4172/2162-6359.1000390 
Inyiama, O. I. \& Ozouli, C. N. (2014). Interactions between exchange rate and financial performance indicators in Nigeria beer industry: Evidence from Nigerian Breweries Plc. Academic Journal of Interdisciplinary Studies, 3(6), 341-352. https://doi.org/10.5901/ajis.2014.v3n6p341

Jongbo O. C. (2014). The impact of real exchange rate fluctuation on industrial output in Nigeria. Journal of Policy and Development Studies, 9(1), 268 - 278. https://doi.org/10.12816/0011197

Kabeer, M. A., Iqbal, A., Najaf, K. \& Najaf, R. (2016). The influences of macro-economic factors on capital market performance in Pakistan. Journal of Business \& Financial Affairs, $5(2), 2-6$.

Kanwal \& Nadeem (2013). The impact of macroeconomic variables on the profitability of listed commercial banks in Pakistan.European Journal of Business and Social Sciences, 2(9), 186-201.

Lasisi, I. O., Dikki, C. A. \& Okpanachi, J. (2018). Empirical determinant of firm's profitability: Evidence from listed agricultural companies in Nigeria. Journal of Management Sciences, 15(8), 67-88.

Muhammad, J. I. \& Naeem, U. K. (2015). Bank Profitability, Inflation and Cost Efficiency-A Case of Pakistani Banks. International Journal of Business andManagement Review, 3(1), 41-53.

Musah, A,. Anokye, F. K. \& Gakpetor, E.D. (2018). The Impact of interest rate spread on bank profitability in Ghana. European Journal of Business Economics and Accountancy, 6(1) 27-39.

Naser, H. \& Abdollah, P. M. (2015). Evaluating the impact of Inflation on profitability of banks. Kuwait Chapter of Arabian Journal of Business andManagement Review, 4(9). https://doi.org/10.12816/0018988

Ncube, M., \& Ndou, E. (2011). Inflation targeting, exchange rate shocks and output: Evidence from South Africa. African Development Bank Group.

Odior, E. S. (2013). Macroeconomic variables and the productivity of the manufacturing sector in Nigeria: A static analysis approach, Journal of Emerging Issues in Economics. Finance and Banking,1(5), 362-380.

Ogunbiyi, S. S. \& Ihejirika, P. O. (2014). Interest rates and deposit money banks' profitability nexus: The Nigerian experience. Arabian Journal of Business and Management Review, 3(11), 133-148. https://doi.org/10.12816/0016525

Okoye, L. U. \& Clement, N. (2015). Influence of finance and macroeconomic variables on manufacturing capacity utilization in Nigeria. Journal of Nigerian Accounting Association, 6(1), 176-188. 


\section{Macrothink}

Asian Journal of Finance \& Accounting

ISSN 1946-052X 2021, Vol. 13, No. 2

Oleka, C. D. Eyisi, A. S. \& Ebue, M. I. (2015). Relationship between inflation and firms' performance-Evidence from Nigeria.World Applied Sciences Journal, 33(5), 814-822.

Onyekwelu, L. U. (2015). Firm Foundation in Accounting and Finance Research. Ist Ed. Enugu: His Glory Publications

Orji, A., Ogbuabor, J. E., \& Okeke, C. (2018). Another side of the Coin: Exchange rate movements and the manufacturing sector in Nigeria. Journal of Infrastructural Development. 10(1-2), 63-79. https://doi.org/10.1177/0974930618811499

Osadume, R. (2018). Effect of interest rate mechanisms on the economic development of Nigeria, 1986 -2016. IIARD International Journal of Economics and Business Management, 4(4), 91-115.

Osamwonyi, I. O., \& Michael, C. I. (2014). The Impact of macroeconomic variables on the profitability of listed commercial banks in Nigeria. European Journal of Accounting Auditing and Finance Research, 2(10), 85-95.

Osoro, C., \& Ogeto, W. (2014). Macroeconomic fluctuations effects on the financial performance of listed manufacturing firms in Kenya. The international journal of social sciences, 21(1).

Osundina, C. K., Osundina, J. A., Jayeoba, O. O. \& Olayinka, I. M. (2016).Exchange rate volatility and banks performance: Evidence from Nigeria. IIARD International Journal of Economics and Business Management, 2(4), 1-11.

Otambo, T. D. (2016). The effect of macro-economic variables on financial performance of commercial banking sector in Kenya.School of Business, University of Nairobi, 1-58.

Owolabi, B. A. (2017). Economic characteristics and financial performance of selected manufacturingcompanies in Nigeria, unpublished master's thesis, Department of Accounting, School of Management Sciences, Babcock University, Ogun State

Owusu-Antwi, G., Banerjee, R., \& Antwi, J. (2017). Interest rate spread on bank profitability: The case of Ghananian banks. Journal of Accounting, Business and Finance Research, 1(1), $34-45$.

Samiloglu, F., Oztop, A. Y. \& Kahraman, Y. E. (2017). Determinants of firm financial performance in Istanbul stock exchange (BIST).IOSR Journal of Economics and Finance (IOSR-JEF), 8(6:1), 62-67.

Samuelson, P., \& Nordhaus, W. (2002).Economy.M.: NGO" Algona" VNIISI, 1, 331.

Segun, O.M. (2018). Measuring the impact of exchange rate on industrial output in Nigeria European Journal of Marketing and Economics, 1(2), 87-93.

Sufian, F. (2011). Profitability of the Korean Banking Sector: Panel evidence on bankspecific and macroeconomic determinants. Journal of Economics and Management, 7(1), 43-72. 


\section{Macrothink}

Tams-Alasia, O., Olokoyo, F. O., Okoye, L. U., \& Ejemeyovwi, J. O. (2018). Impact of exchange rate deregulation on manufacturing sector performance in Nigeria. International Journal of Environment Agriculture and Biotechnology, 3(3), 0994-1001.

Ubesie, M. C. (2016). The effect of variations in foreign exchange on financial depth: Evidence from Nigeria. European Journal of Accounting, Auditing and Finance Research, $4(4), 56-64$

Ugwu, O. J. (2017). Foreign exchange rate dynamics and manufacturing firms' performance in Nigeria. International Journal of Humanities and Social Science Invention, 6(9), 09-14.

Umaru, A. \& Zubairu, A. A. (2012). Effect of inflation on the growth and development of the Nigerian Economy. International.

Wang, W. (2016).Vertical specialization and enlarging the size of the economy. https://www.sciencedirect.com/topics/economics-e

Williams, H. T. (2018). An empirical investigation of the impact of exchange rate fluctuations on the performance of selected listed firms in Nigeria. Journal of Business Management and Economic Research, 2(3), 1-10. 